\title{
Analisis Kesulitan Siswa dalam Mengerjakan Soal pada Materi Aritmatika Sosial Kelas VII
}

\author{
Siti Mariam Marlina ${ }^{1}$, Wahyu Setiawan ${ }^{2}$ \\ ${ }^{1,2}$ SMP Al - Barokah Sindangkerta, Desa Cikadu Kecamatan Sindangkerta, Kabupaten Bandung Barat, \\ IKIP Siliwangi Bandung, Jl. Terusan Jendral Sudirman, Cimahi, Indonesia \\ sitipsnangka22@gmail.com
}

\begin{abstract}
This research is a descriptive, the objective of this study is to find out the student difficulties in working on social arithmetic question. This research was conducted on seven grade students at Al - Barokah Sindangkerta Junior Hight School. The method used in this study is descriptive method. The date was analyzed by using interview and questionnaire material social arithmetic. The results of analyzes of the matter indicate that the level of students' ability in working on arithmetic questions on number 1 is still low, while in the number 2, 3, 4 and 5 questions, students have been able to work on the questions properly and correctly. The results of the interviews prove that social arithmetic material is very important to be studied and understood by students because social arithmetic is the basic science of the community in daily life and can be said of social arithmetic often carried out by the community. From the results of this study it was found that several factors that influenced students difficulties in working on social arithmetic problems, namely the lack of student interest in learning, lack of understanding of students mathematical concepts on social arithmetic material, students lacking motivation and students lackingpractice working on the questions, and in this study the researchers got the tyfes of errors which were analized using the Newman stage procedure, in which the tyfes of errors students experienced were misunderstood questions, transformation errors, process skill errors and writing error answer.
\end{abstract}

Keywords: Difficulty index, Social Arithmetic

\begin{abstract}
Abstrak
Penelitian ini bertujuan untuk mengetahui tingkat kesulitan siswa dalam mengerjakan soal aritmatika soaial. Penelitian ini telah dilaksanakan di kelas 7 SMP Al- Barokah Sindangkerta pada tanggal 19 April 2021. Metode penelitian yang digunakan pada penelitian ini yaitu metode deskriftif, data yang dianalisis adalah wawancara dan soal materi aritmatika sosial. Hasil analisis butir soal menunjukkan bahwa tingkat kemampuan siswa dalam mengerjakan soal aritmatika pada soal nomor 1 masih rendah, sedangkan pada soal nomor 2, 3, 4 dan 5 siswa sudah mampu mengerjakan soal dengan baik dan benar. Hasil wawancara membuktikan bahwa materi aritmatika sangat penting dipelajari dan dipahami oleh siswa karena aritmatika sosial adalah ilmu dasar masyarakat dalam kehidupan sehari - hari, dan dapat dikatakan aritmatika sosial sering dilakukan oleh masyarakat. Dari hasil penelitian ini didapatkan hasil beberapa faktor yang mempengaruhi siswa kesulitan dalam mengerjakan soal aritmatika sosial yaitu kurangnya minat siswa dalam belajar, kurangnya pemahaman konsep matematis siswa terhadap materi aritmatika sosial, siswa kurang motivasi dan siswa kurang berlatih mengerjakan soal, serta dalam penelitian ini peneliti mendapatkan tife - tife kesalahan siswa yang dianalisis menggunakan prosedur tahapan Newman, yang mana tife kesalahan siswa yang dialami yaitu kesalahan memahami soal, kesalahan transformasi, kesalahan keterampilan proses dan kesalahan penulisan jawaban.
\end{abstract}

Kata kunci: Indeks Kesukaran, Aritmatika Sosial

Copyright (c) 2021 Siti Mariam Marlina, Wahyu Setiawan

$\triangle$ Corresponding author: Siti Mariam Marlina

Email Address: sitipsnangka22@gmail.com (Jl. Terusan Jendral Sudirman, Cimahi, Indonesia)

Received 24 May 2021, Accepted 14 June 2021, Published 05 August 2021

\section{PENDAHULUAN}

Belajar adalah suatu aktivitas yang sering dilakukan secara terus menerus baik itu dalam pendidikan formal ataupun non formal, dan belajar juga tidak memandang usia, baik itu anak muda ataupun orang tua sekalipun selama usia manusia masih ada belajar diharuskan, dan bahkan belajar atau menuntut ilmu itu sudah tercantum dalam hadist nya dan orang yang senantiasa belajar akan memiliki pengetahuan dan ilmu yang baik, dan tentunya orang yang berilmu akan berbeda dengan orang yang tidak berilmu. Terutama untuk 
para siswa, belajar sangat penting karena siswa adalah cikal bakal penerus bangsa sebagai generasi emas. Belajar adalah suatu aktivitas manusia yang dapat mencerminkan kualitas dan juga kuantitas manusia satu dengan manusia yang lainnya, baik dari tingkah laku, komunikasi, keterampilan dan juga cara berpikir seseorang (Ni Luh Putu Ekayani, 2017). Karena belajar sangat penting untuk semua kalangan, karena proses belajar akan memberikan pengalaman dan kemampuan tertentu pada seseorang, selain dari itu belajar yang merupakan aktivitas pendidikan sangat berpengaruh penting karena untuk mengembangkan dan juga meningkatkan potensi pengendalian diri seseorang (Fina Kamilatus Z \& Fina Rahmatika, 2019). Salah satu mata pelajaran yang sangat penting dipelajari adalah mata pelajaran matematika.

Matematika adalah salah satu mata pelajaran yang banyak digunakan dalam kehidupan sehari - hari, karena dasar - dasar ilmu matematika sering digunakan dalam berbagai aktivitas masyarakat, salah satu aktivitas masyarakat yang melibatkan konsep - konsep matematika adalah kegiatan jual beli, menentukan angsuran pokok pinjaman, menentukan diskon dan banyak lagi aktivitas lainnya. Oleh karena itu matematika merupakan cabang ilmu pengetahuan yang menunjang ilmu pengetahuan lainnya yang berkaitan dengan kehidupan sehari - hari (Rahmawati, et. al., 2019, Akbar, et. al., 2018 Diniyah, et. al., 2018:14). Pernyataan serupa yang membuktikan bahwa matematika adalah mata pelajaran yang harus di pelajari adalah karena matematika merupakan ratu ilmu atau induknya ilmu pengetahuan yang lain Russefendi (Yanti et. al., 2019). Maka dari itu matematika merupakan mata pelajaran pokok yang sangat penting untuk diajarkan kepada siswa dalam setiap jenjang pendidikan baik pendidikan formal pada tingkat sekolah dasar, sekolah menengah ataupun sekolah menengah atas sebagai pembelajaran yang essensial (Iasha Nur Afifah Khodijah et.al, 2018). Dalam mata pelajaran matematika banyak cakupan materi - materi yang yang harus dipelajari, antara lain aljabar, aritmatika sosial, statistika dan masih banyak materi - materi terkait yang harus dipelajari.

Namun pada kenyataannya masih banyak siswa yang mengalami berbagai kesulitan dalam memahami mata pelajaran matematika. Kesulitan siswa dalam memahami matematika memiliki berbagai karakteristik yang bermacam - macam, dan apabila di bandingkan dengan mata pelajaran yang lain matematika dapat di kategorikan sebagai mata pelajaran yang memiliki tingkat kesulitan yang variatif. Menurut Wood (2007 : 68 dalam Sinta Ratnasari \& Wahyu Setiawan) bahwa beberapa karakteristik kesulitan siswa dalam belajar matematika adalah: (1) kesulitan membedakan angka, symbol, serta bangun ruang, (2) tidak sanggup mengingat dalil - dalil matematika, (3) menulis angka tidak terbaca atau dalam ukuran kecil, (4) tidak memahami symbol-simbol matematika, (5) lemahnya kemampuan berpikir abstrak, (6) lemahnya kemampuan meta kognisi (lemahnya kemampuan mengidentifikasi serta memanfaatkan algoritma dalam memecahkan masalah.

Salah satu materi matematika yang banyak dianggap sulit dan terkadang membingungkan siswa baik dalam materi ataupun soal adalah materi aritmatika sosial, aritmatika sosial adalah bagian dari matematika yang membahas perhitungan keuangan dalam perdagangan dan kehidupan sehari - hari beserta aspek aspeknya hal ini dikemukakan oleh (Karso,2007:1 dalam Nandya Paramitha \& Tri Nova H.Y : 2017). Dan materi ini dapat dipelajari siswa Sekolah Menengah Pertama (SMP) pada kelas VII di semester 1. Isi dari 
Analisis Kesulitan Siswa Dalam Mengerjakan Soal Pada Materi Aritmatika Sosial Kelas VII, Siti Mariam Marlina, Wahyu Setiawan

materi aritmatika sosial membahas tentang (1) untung dan rugi; (2) harga jual dan harga beli; (3) rabat dan diskon; (4) bruto, neto dan tara; (5) bunga tabungan. Khususnya dalam soal aritmatika sosial siswa sangat banyak mengalami kesulitan, dikarenakan pada soal aritmatika sosial banyak melibatkan soal cerita dalam penyajiannya. Soal cerita adalah salah satu soal yang penyajiannya menggunakan soal cerita yang membahas kegiatan sehari-hari Budiyono (2008:8 dalam Fahmi Abdul H \& Nilta Ilmiyatul R: 2019). Maka dapat dilihat dari pendapat Budiyono dari hasil penelitian - penelitian sebelumnya bahwa soal aritmatika sosial sangat sulit apabila siswa tidak dapat membaca dan memahami soal cerita. Beberapa aspek dalalam menyelesaikan soal cerita matematika yaitu: 1) Aspek Bahasa; 2) Aspek prasyarat; dan 3) Aspek terapan.

Kesulitan yang di alami oleh siswa dalam mengerjakan soal materi aritmatika sosial salah satunya karena siswa kurang teliti dalam memahami soal cerita yang ada di dalam soal, sehingga ketika menjawab soal siswa mendapatkan kesulitan. Kemudian faktor lain yang menyebabkan siswa kesulitan dalam mengerjakan soal aritmatika sosial karena siswa masih mengalami kesulitan dalam perhitungan, baik penjumlahan, pengurangan, perkalian maupun pembagian hal ini dikemukakan oleh Agniditya (dalam Evijayanti, 2016).

Berdasarkan aspek kurangnya pemahaman konsep ini dapat dilihat bahwa pemahaman siswa masih sangat kurang optimal, pada hal ini disebabkan konsep dasar aritmatika sosial atau materi pra syarat aritmatika sosial belum terpahami oleh siswa sebelumnya, dan beberapa faktor lain yang sering ditemukan akibat siswa kesulitan terhapap materi maupun soal aritmatika sosial karena dipengaruhi oleh beberapa faktor, yaitu kurang motivasi, kurang nya kesadaran siswa akan pentignya mempelajari materi aritmatika sosial, kurangnya minat belajar siswa serta siswa kurang rajin dalam mengasah kemampuannya agar melatih diri dengan memperbanyak mengerjakan latihan soal.

Kemudian apabila dilihat dari faktor kurangnya minat belajar yang ada dalam diri siswa sendiri yang menyebabkan siswa mengalami kesulitan dalam belajar matematika, sedangkan minat belajar merupakan ketertarikan dan kesenangan siswa terhadap sesuatu hal yang diiringi dengan semangat yang tinggi. minat yaitu suatu tindakan yang menimbulkan rasa atau perasaan senang, serta rasa ketertarikan terhadap sesuatu. Sedangkan menurut Crow and Crow menyatakan bahwa minat sangat berhubungan erat dengan gaya yang mendorong seseorang untuk menghadapi atau berurusan dengan orang, benda, kegiatan, pengalaman yang dirangsang oleh kegiatan itu sendiri (Nunung Hamidah \& Wahyu Setiawan, 2015). Sehingga dalam kurangnya minat belajar siswa terhadap matematika khususnya pada materi aritmatika sosial akan mengalami penurunan terhadap pemahaman matematis siswa yang mengakibatkan siswa mengalami kesulitan dalam menjawab atau mengisi soal cerita pada aritmatika sosial. Arikunto berpendapat bahwa ketika seseorang belajar tanpa memiliki minat mungkin akan cenderung bosan (Arikunto, 2007 dalam Nunung Hamidah \& Wahyu Setiawan, 2015) dan hal ini memang banyak dialami sebagian besar siswa, ketika mereka sudah mentok dan merasa kesulitan dalam mengerjakan soal maka pilihan yang siswa ambil adalah menyerah, bosan dan mengerjakan soal asal - asalan, hal. Beberapa faktor lain yang mempengaruhi adalah kurangnya motivasi siswa dalam belajar, sedangkan motivasi belajar sangat berpengaruh untuk meningkatkan semangat siswa dan keaktifan siswa dalam belajar, motivasi belajar dapat diberikan baik itu 
oleh orang tua, teman sebaya, guru dan lingkungan sekitar yang mendukung. Adapun indikator-indikator motivasi belajar dapat di klasifikasikan sebagai berikut: 1) Adanya hasrat ingin berhasil; 2) Adanya dorongan dan kebutuhan dalam belajar; 3) Adanya harapan dan cita-cita masa depan; 4) Adanya penghargaan dalam belajar; 5) Adanya kegiatan yang menarik dalam belajar; 6) adanya lingkungan yang kondusif.

Selain dari kurangnya pemahaman konsep, kurangnya minat belajar siswa, kurangnya motivasi belajar, penyebab lain siswa mengalami kesulitan dalam mengerjakan soal aritmatika sosial karena pemahaman dasar siswa pada materi aritmatika, hal ini sebagaimana yang telah disebutkan diatas. Syarat utama bagi siswa untuk menyelesaikan soal terutama soal yang tidak rutin adalah adanya pengetahuan dasar, hal ini dikemukakan oleh Ruseffendi 2006 (dalam Apri Kurniawan \& Nelly Fitriani: 2020).

Kemudian diperkuat oleh penelitian yang sudah dilakukan oleh Lestari (Zulfikar, Achmad, \& Fitriani,2018) menyimpulkan bahwa kesalahan siswa dalam menyelesaikan soal generalisasi adalah belum memahami soal, sukar dalam menentukan strategi yang digunakan dan terjadinya miskonsepsi aatau kurangnya materi prasyarat. Dan ternyata bukan hanya itu faktor siswa kesulitan dalam mengerjakan soal aritmatika sosial, tetapi juga dikarenakan siswa kurang tidak mengerti dan kurang memahami kata-kata atau kalimat apa yang terkandung dalam soal cerita pada materi aritmatika sosial. Sebagaimana penelitian terdahulu yang telah dilakukan menyimpulkan bahwa kesulitan siswa dalam mengerjakan soal cerita pada materi aritmatika sosial yaitu dikarenakan siswa kurang mengerti dan memahami bahasa yang digunakan dalam soal cerita.

Hal lain yang mempengaruhi keslitan siswa dalam mengerjakan soal aritmatika sosial adalah pemikiran siswa yang cenderung memandang negatif mata pelajaran matematika yaitu siswa menganggap mata pelajaran matematika sangat sulit, dan hal itu memicu siswa menjadi malas mengerjakan soal matematika, khsusnya pada materi aritmatika sosial.

Beberapa karakteristik-karakteristik siswa kesulitan belajar matematika yang dapat menyebabkan siswa kesulitan dalam mengerjakan soal aritmatika sosial menurut lerner dalam (Abdurrahman,2010:259 dalam Firmansyah, Sofnindar \& Rohaeti : 2018) yaitu : 1) Adanya gangguan dalam hubungan keruangan; 2) Abnormalitas persefsi visual; 3) Asosiasi visual-motor; 4) perseversi; 5) Kesulitan memahami symbol; 6) Gangguan penghayatan tubuh; 7) Kesulitan dalam Bahasa dan membaca; 8) Performance IQ jauh lebih rendah daripada skor verbal IQ. Berdasarkan latar belakang diatas tujuan penelitian ini adalah untuk menganalisis tingkat kesulitan siswa dalam mengerjakan soal pada materi aritmatika sosial kelas VII untuk mendapatkan hasil yang signifikan terkait penelitian yang dilakukan agar mengetahui tiap butir soal yang tergolong mudah, sedang dan sulit.

\section{METODE}

Penelitian ini merupakan jenis penelitian deskriftif. Yang tujuannnya untuk menganalisis kesulitan siswa dalam mengerjakan soal pada materi aritmatika sosial kelas VII. Dengan ini peneliti melakukan penelitian untuk mencari tingkat kesulitan tiap butir soal yang tergolong mudah, sedang dan sulit dalam 
mengerjakan soal, dan untuk mendapatkan hasil yang diinginkan, peneliti memberikan instrumen soal yang sudah valid. Dan dari setiap analisis yang dilakukan akan diketahui tingkat kesulitan siswa terhadap jawaban yang diberikan siswa terhadap butir soal yang di kategorikan mudah, sedang dan sulit. Butir soal tes terdiri dari 5 soal uraian materi aritmatika sosial yang diberikan kepada kelas VII, dengan lokasi penelitian di SMP $\mathrm{Al}$ - Barokah Sindangkerta dengan objek penelitian sebanyak 20 siswa kelas VII. Cara pengumpulan data yang dilakukan yaitu dengan memberikan 5 butir soal yang dibuat oleh peneliti sendiri yang sudah di cek tingakat validasinya dan layak untuk di gunakan, dan soal yang digunakan peneliti diberikan kepada 20 orang siswa sebagai responden pada penelitian ini.

\section{HASIL DAN DISKUSI}

\section{Hasil}

Penelitian ini dilakukan pada siswa di kelas VII SMP Al- Barokah Sindangkerta dengan siswa yang berjumlah 20 orang siswa, dan sebagai langkah pertama tindakkan pada penelitian ini, peneliti memberikan soal tes diagnostik yang bertujuan untuk mengetahui samapai dimana tingkat kemampuan pemahaman siswa pada materi aritmatika sosial. Dasar analisis perhitungan untuk menentukan tingkat kesulitan siswa pada setiap butir soal materi aritmatika social.

Tabel 1. (Kriteria Indeks Kesukaran)

\begin{tabular}{|c|c|}
\hline IK (Indeks Kesukaran) & Intrepretasi \\
\hline $\mathrm{IK}=0$ & Soal terlalu sukar \\
\hline $0,00<\mathrm{IK} \leq 0,30$ & Soal sukar \\
\hline $0,30<\mathrm{IK} \leq 0,70$ & Soal sedang \\
\hline $0,70<\mathrm{IK} \leq 1,00$ & Soal mudah \\
\hline
\end{tabular}

Dan hasil yang di dapatkan dari analisis butir soal dengan menggunakan perhitungan indeks kesukaran ini ditunjukkan dengan data tabel dibawah ini:

Tabel 2. (Hasil Indeks Kesukaran Butir Soal Siswa)

\begin{tabular}{|c|c|c|}
\hline Butir Soal & Indek kesukaran yang dihasilkan & Intreupretasi \\
\hline 1 & 0,03 & Soal Sukar \\
\hline 2 & 0,53 & Soal Sedang \\
\hline 3 & 0,55 & Soal Sedang \\
\hline 4 & 0,56 & Soal Sedang \\
\hline 5 & 0,72 & Soal Mudah \\
\hline
\end{tabular}

Selanjutnya analisis butir soal ini juga menggunakan kriteria pemahaman berdasarkan yang dikemukakan oleh Arikunto 2008 (dalam Sinta Ratnasari \& Wahyu Setiawan) dengan memperhatikan batasan-batasan kriteria yang dikemukakan oleh Arikunto 2008 (dalam Sinta Ratnasari \& Wahyu Setiawan) untuk menganalisis pemahaman siswa terhadap butir soal, karena pemahaman siswa terhadap penyelesaian masalah dalam soal sangat mempengaruhi tingkat kesulitan siswa pada setiap butir soal-nya. Dan data menurut Arikunto 2008 (dalam Sinta Ratnasari \& Wahyu Setiawan) ditunjukkan pada tabel di bawah ini: 
Tabel 3. Kriteria Data

\begin{tabular}{|c|c|}
\hline Persentase & Kriteria \\
\hline $81 \%-100 \%$ & Baik Sekali \\
\hline $61 \%-80 \%$ & Baik \\
\hline $41 \%-60 \%$ & Cukup \\
\hline $21 \%-40 \%$ & Kurang \\
\hline $0 \%-20 \%$ & Kurang Sekali \\
\hline
\end{tabular}

Dengan kriteria yang di kemukakan Arikunto 2008 (dalam Sinta Ratnasari \& Wahyu Setiawan) didapatkan hasil analisis terhadap butir soal untuk mengukur tingkat kesulitan siswa dilihat dari aspek pemahaman siswa yang di tunjukkan dengan tabel dibawah ini:

Tabel 4. Hasil Analisis Kesulitan Siswa Pada Butir Soal Menurut Arikunto dari Aspek Pemahaman Siswa Terhadap Tiap Butir Soal

\begin{tabular}{|c|c|c|c|c|}
\hline $\begin{array}{c}\text { No. } \\
\text { Soal }\end{array}$ & $\begin{array}{c}\text { Siswa Yang } \\
\text { Menjawab Benar }\end{array}$ & Persentase & $\begin{array}{c}\text { Siswa Yang Menjawab } \\
\text { Salah }\end{array}$ & Persentase \\
\hline 1 & 4 & $20 \%$ & 16 & $80 \%$ \\
\hline 2 & 7 & $35 \%$ & 13 & $65 \%$ \\
\hline 3 & 13 & $65 \%$ & 7 & $35 \%$ \\
\hline 4 & 16 & $80 \%$ & 4 & $20 \%$ \\
\hline 5 & 15 & $75 \%$ & 5 & $25 \%$ \\
\hline
\end{tabular}

Setelah didapatkan hasil terhadap analisis butir soal, maka peneliti sajikan dalam suatu bentuk diagram batang berikut dibawah ini:

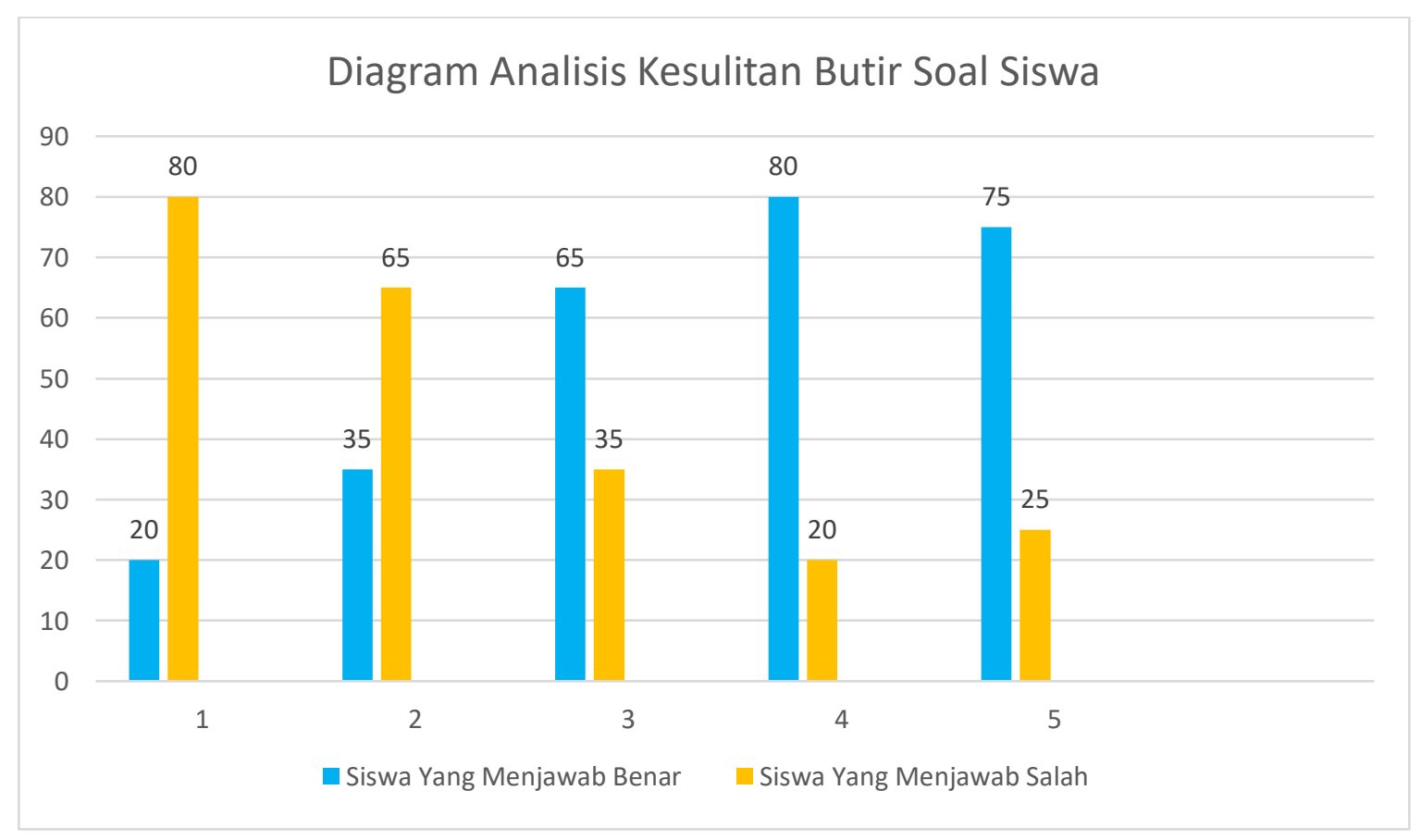

Gambar 1. Diagram Analisis Kesulitan Butir Soal Siswa

Dari data - data yang diperoleh diatas, maka dapat disimpulkan bahwa siswa yang paling banyak 
Analisis Kesulitan Siswa Dalam Mengerjakan Soal Pada Materi Aritmatika Sosial Kelas VII, Siti Mariam Marlina, Wahyu Setiawan

menjawab salah terdapat pada butir soal nomor 1, dan kemudian siswa yang banyak menjawab soal dengan benar terdapat pada soal nomor 4. Maka dari hasil analisis diatas, siswa banyak yang mengalami kesulitan dalam mengerjakan soal aritmatika pada soal nomor 1 yaitu mengenai harga jual dan harga beli.

Dalam penelitian ini juga, untuk memperkuat analisis yang peneliti lakukan agar mendapatkan hasil yang akurat mengenai kesalahan siswa dalam mengerjakan soal aritmatika sosial yaitu dengan menggunakan prosedur Newman. Newman membagi lima tife kesalahan dalam langkah kegiatan yang spesifik, antara lain membaca (reading), memahami (comprehension), transformasi (transformation), keterampilan proses (process skill) dan penulisan (encoding).

Sebelum peneliti menyajikan analisis kesalahan siswa dalam mengerjakan soal aritmatika sosial dengan menggunakan prosedur Newman, terlebih dahulu peneliti sampaikan hasil observasi awal yang peneliti lakukan, yaitu dengan melakukan wawancara terhadap guru dan siswa, hasil yang didapatkan dari wawancara guru mata pelajaran matematika di SMP Al-Barokah adalah sebagai berikut:

1. Masih banyak siswa yang kurang memahami konsep aritmatika sosial

2. Masih banyak siswa yang bingung dalam mengerjakan soal uraian karena dalam penyajian soalnya banyak melibatkan soal cerita.

3. Masih banyak siswa yang sering mengabaikan penulisan apa yang diketahui dan apa yang ditanyakan pada soal, sehingga siswa sering keliru dalam mengerjakan soal.

Kemudaian hasil wawancara yang diperoleh dari 20 orang siswa yang menjawab sama adalah sebagai berikut :

Peneliti $\quad$ : Apakah kalian menyukai materi aritmatika sosial pada mata pelajaran matematika?

Responden : Suka

Peneliti $\quad$ : Menurut kalian materi aritmatika sosial sulit atau mudah?

Responden : Susah-susah gampang

Peneliti $\quad$ : Apakah kalian suka mengalami kesulitan dalam mengerjakan soal aritmatika sosial?

Responden : Sering

Peneliti $\quad$ : Kenapa kalian sering mengalami kesulitan dalam mengerjakan soal?

Responden : Karena soalnya banyak ceritanya

Peneliti $\quad$ : Selain dari kalian kesulitan mengerjakan soal karena banyak soal ceritanya, apalagi kendala yang sering kalian temukan dalam mengisi soal aritmatika sosial?

Responden : Tidak hapal rumus, bingung menentukan apa yang diketahui.

Dari hasil wawancara yang diperoleh, baik hasil dari wawancara guru maupun siswa, maka dapat diketahui apa permasalahan dan kesulitan siswa dalam mengerjakan soal aritmatika sosial, siswa mengalami kesulitan dalam mengerjakan soal aritmatika sosial yaitu karena siswa kurang memahami konsep aritmatika sosial, siswa bingung mengerjakan soal cerita karena sulit menentukan apa yang diketahui dana pa yang ditanyakan sebenarnya. Dan untuk analisis selanjutnya kita akan menganalisis kesulitan siswa dalam mengerjakan soal aritmatika sosial dengan menggunakan prosedur Newman, sebagai berikut:

Soal nomor 1 
Pak Udin sudah mengeluarkan biaya Rp. 1.000.000, untuk membuat kandang kambing, dan sudah membeli bibit kambing jantan dengan usia 5 bulan dengan harga Rp. 800.000/ekor, dan Pak Udin membeli 10 ekor kambing jantan, kemudian untuk pakan rumput, vitamin, dan lainya sebesar Rp.1.000.000/bulan. Dari informasi di atas, Tentukanlah modal awal yang dikeluarkan Pak Udin?

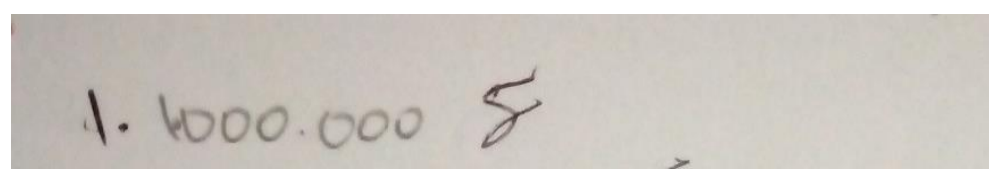

Gambar 1. (contoh kesalahan siswa menjawab soal dalam tahap analisis Newman)

Terlihat dari gambar 1 di atas yang menunjukkan bahwa siswa sudah menerapkan tahap analisis Newman, hanya saja siswa melakukan tahap analisis Newman hanya sampai tahap membaca saja, sedangkan pada tahap memahami, transformasi, keterampilan proses dan penulisan masih belum diterapkan, siswa tidak menuliskan informasi - informasi penting seperti apa yang diketahui dan apa yang ditanyakan dari soal, maka itu berarti siswa tidak memahami soal yang diberikan. Pada tahapan transformasi siswa masih belum menuliskan rumus apa yang akan digunakan dalam mengerjakan soal ini, sehingga dari gambar 1 yang terlihat siswa langsung menuliskan jawabannya saja, tanpa memperhatikan rumus dan langkah - langkah pengerjaan soal yang akan digunakan, sehingga siswa tidak dapat mengembangkan tahap keterampilan proses karena jawaban yang dituliskan siswa keliru, seharusnya jawabannya adalah modal awal $=$ Pembuatan kandang + Pembelian bibit kambing (10 ekor $x$ Rp. 800.000,00) + Pakan dan vitamin Sehingga modal awal $=1.000 .000+8.000 .000+1.000 .000=10.000 .000$, jadi jawabannya yang tepat adalah 10.000 .000 .

Kemudian pada soal nomor 2:

Dari soal 1 jika setelah 10 bulan dipelihara, kemudian dijual dengan harga Rp. 2.600.000-/ekor, maka hitunglah:

a. Berapa keuntungan yang diperoleh Pak udin dari hasil ternak selama 10 bulan?

b. Dan berapa besar pendapatan Pak Udin jika di hitung per bulan?

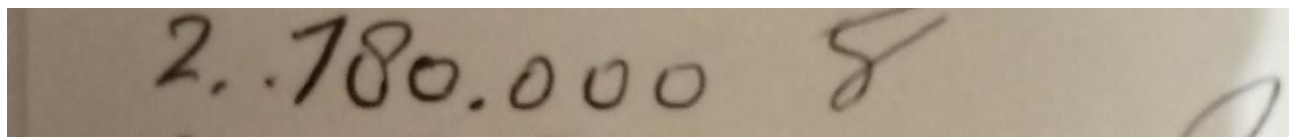

Gambar 2. (Kesalahan siswa terhadap tahapan analisis Newman pada soal nomor 2)

Tipe kesalahan siswa terhadap tahap analisis Newman pada soal nomor 2 ini sama dengan soal nomor 1, yang mana siswa tidak menerapkan tahapan memahami, transformasi, keterampilan proses dan penulisan. Sebagaimana yang terlihat, dalam soal terdapat 2 poin pertanyaan dalam satu soal, akan tetapi siswa menuliskan satu jawaban saja tanpa ada keterangan jawaban tersebut untuk poin a atau poin $b$, sehingga dalam menjawab soal siswa masih keliru. Dan dari gambar 2 terlihat bahwa siswa tidak menggunakan pendekatan atau rumus apa yang akan digunakan, siswa pun tidak menuliskan apa yang diketahui dana pa yang ditanyakan. Sehrusnya jawaban yang tepat pada point a adalah menggunakan rumus "Keuntungan = 
Analisis Kesulitan Siswa Dalam Mengerjakan Soal Pada Materi Aritmatika Sosial Kelas VII, Siti Mariam Marlina, Wahyu Setiawan

Harja jual - Harga Beli, maka Keuntungan Pak Udin $=(2.600 .000$ x 10 ekor $)-$ Modal awal $=26.000 .000-10.000 .000=16.000 .000$, jadi keuntungan Pak Udin adalah 16.000.000. sedangkan untuk point b siswa seharusnya menggunakan rumus "Keuntungan Pak Udin/ bulan = Keuntungan: 10 bulan Maka 16.000.000: 10 bulan $=1.600 .000$, jadi keuntungan Pak Udin perbulannya adalah 1.600.000.

Pada soal nomor 3 dan 4 tipe kesalahan yang dilakukan siswa sama dengan apa yang telah di jelaskan pada soal nomor 1 dan nomor 2 yakni siswa belum melakukan tahapan analisis Newman pada tahap memahami, transformasi, keterampilan proses dan penulisan.

Kemudian pada soal nomor 5:

Pak dayat memulai usaha bakso pada awal bulan November 2019 dengan modal awal Rp.1.000.000.00, Pak Dayat menjual bakso dengan harga 15.000.00 per mangkuk dan di bulan November Pak Dayat berhasil menjual 80 mangkuk bakso, sedangkan pada bulan Desember Pak Dayat hanya dapat menjual 65 mangkok bakso. Dari informasi di atas:

a. Hitunglah pendapatan bulan November?

b. Hitunglah pendapatan bulan Desember?

c. Dilihat dari point a dan b maka Pak Dayat mengalami keuntungan pada bulan?

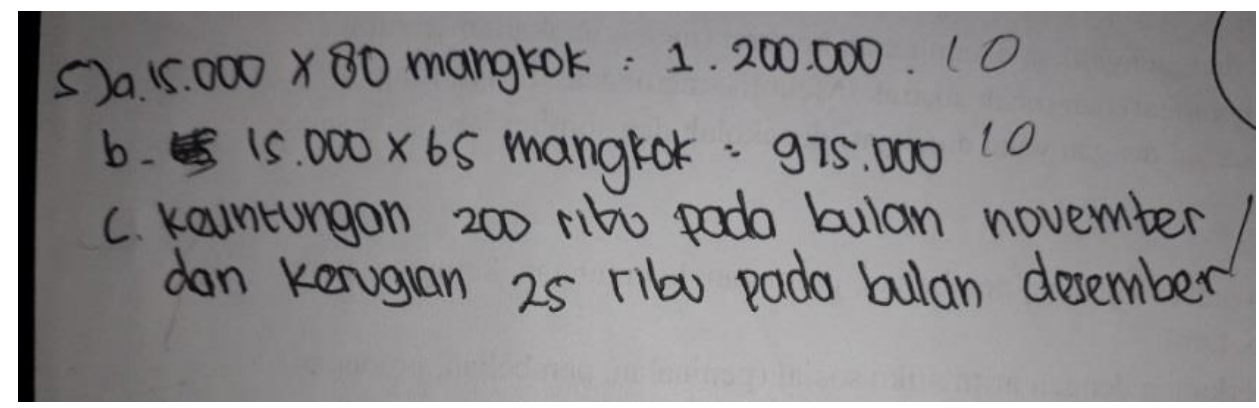

Gambar 3. Jawaban siswa terhadap analisis tahapan Newman pada soal nomor 5

Dari hasil jawaban siswa terhadap soal nomor 5 terlihat bahwa siswa sudah dapat memahami apa yang ditanyakan pada soal yang tersaji pada soal nomor 5, dalam hal ini tahapan transformasi sudah diterapkan oleh siswa, yakni siswa sudah mulai menggunakan pendekatan dan rumus yang seharusnya digunkan pada soal nomor 5, siswa pun sudah dapat menjawab dengan tepat. Akan tetapi siswa masih mengabaikan tahapan keterampilan proses yang mana siswa tidak menuliskan terlebih dahulu apa yang diketahui dan apa yang ditanyakan terkait iformasi - informasi yang di dapatkan dari soal.

Maka dari berbagai tahapan analisis Newman yang sudah dianalisis dari hasil jawaban siswa, maka peneliti akan menyajikan tife - tife kesalahan siswa agar lebih akurat dan lebih jelas, sebagaimana yang tercantum pada tabel 1.5 dibawah ini:

Tabel 4. Tabel Faktor dan Indikator Kesalahan Siswa

\begin{tabular}{|c|c|cl|}
\hline No & $\begin{array}{c}\text { Faktor Kesalahan } \\
\text { Siswa }\end{array}$ & \multicolumn{2}{c|}{ Indikator } \\
\hline \multirow{2}{*}{1} & Membaca (Reading) & a. & Siswa tidak mampu membaca symbol - symbol dalam soal \\
\cline { 3 - 4 } & & b. & Siswa tidak memahami maksud dari setiap kalimat yang ada dalam \\
\hline
\end{tabular}




\begin{tabular}{|c|c|c|}
\hline & & soal cerita \\
\hline \multirow{3}{*}{2.} & \multirow{3}{*}{$\begin{array}{c}\text { Memahami } \\
\text { (Comprehension) }\end{array}$} & $\begin{array}{l}\text { a. Siswa tidak dapat memahami informasi - informasi terkait dalam } \\
\text { soal }\end{array}$ \\
\hline & & b. Siswa tidak memahami apa yang diketahui dari soal dengan lengkap \\
\hline & & $\begin{array}{l}\text { c. Siswa tidak memahami apa yang seharusnya ditanyakan dalam soal } \\
\text { aritmatika sosial. }\end{array}$ \\
\hline \multirow{2}{*}{3.} & \multirow{2}{*}{$\begin{array}{l}\text { Transformasi } \\
\text { (Transformation) }\end{array}$} & $\begin{array}{l}\text { a. Siswa masih belum bisa menyesuaikan atau menggunakan } \\
\text { pendekatan atau rumus yang tepat untuk menyelesaikan soal }\end{array}$ \\
\hline & & $\begin{array}{l}\text { b. Siswa keliru dalam menggunakan operasi hitung yang seharusnya } \\
\text { digunakan dalam menyelesaikan soal }\end{array}$ \\
\hline 4. & $\begin{array}{l}\text { Pemahaman Proses } \\
\text { (Process Skill) }\end{array}$ & $\begin{array}{l}\text { a. Siswa tidak mengetahui langkah - langkah pengerjaan soal untuk } \\
\text { menyelesaikan permasalahan yang terdapat dalam soal }\end{array}$ \\
\hline \multirow{3}{*}{5} & \multirow{3}{*}{$\begin{array}{l}\text { Penulisan Jawaban } \\
\text { (Encoding) }\end{array}$} & Siswa tidak dapat menemukan hasil akhir dari soal yang disajikan \\
\hline & & b. Siswa keliru dalam menuliskan hasil akhir jawaban soal \\
\hline & & $\begin{array}{l}\text { c. Siswa tidak dapat menuliskan hasil akhir yang sesuai dan tepat } \\
\text { dengan kesimpulan yang seharusnya. }\end{array}$ \\
\hline
\end{tabular}

\section{Diskusi}

Berdasarkan penelitian analisis kesulitan siswa terhadap butir soal aritmatika sosial adalah karena dipicu oleh kurang nya minat belajar siswa terhadap mata pelajaran matematika yang mungkin didasari atas berbagai faktor yang dihadapi dan dirasakan siswa, yang diantaranya karena mata pelajaran matematika dianggap sangat sulit dan susah dipahami. Sedangkan minat belajar siswa itu sendiri sangat diperlukan dan berpengaruh besar terhadap siswa, minat adalah suatu rasa lebih suka serta rasa ketertarikan terhadap sesuatu (Slameto, 2010 dalam Nunung Hamidah \& Wahyu Setiawan). Sedangkan menurut Crow and Crow bahwa minat berhubungan erat dengan gaya yang mendorong seseorang untuk menghadapi atau berurusan dengan orang, benda, kegiatan dan pengalaman yang dirangsang oleh kegiatan itu sendiri.

Selain dari kurangnya minat belajar siswa kesulitan siswa terhadap matematika khususnya materi aritmatika sosial yaitu kurangnya pemahaman konsep siswa terhadap materi yang diberikan, karena pemahaman konsep siswa terhadap suatu materi itu sangat menunjang dan sangat menentukan kualitas dan juga tingkat mudah atau sulitnya siswa dalam menjawab soal. Dan juga siswa belum bisa mengoprasikan konsep atau rumus - rumus matematika yang telah diberikan sebelumnya. Dan hal ini diperkuat juga dengan penelitian yang telah dilakukan oleh zulvia (2017:187 dalam Nadya Mastrin A.F, Alpha Galih A \& Marsyah Rahmawati U: 2018) yaitu belum memahami model atau kalimat matematika, belum biasa membedakan antara jawaban model atau kalimat matematika dengan jawaban soal akhir.

Kemudian penelitian ini diperkuat juga dengan penelitian terdahulu yang pernah dilakukan oleh Evijayanti \& Khotimah (2018 dalam Rini Nuraeni, et., al.) yang menunjukkan bahwa dalam menyelesaikan soal cerita aritmatika sosial terdiri dari tiga macam kesulitan yang dihadapi siswa, yakni (1) Kesulitan dalam memahami soal; (2) Siswa kesulitan dalam membuat permodelan matemaatika dan yang ke ; (3) siswa kesulitan dalam proses penyelesaian, dan faktor - faktor diatas terjadi karena siswa tidak teliti dalam membaca soal dan siswa sering terburu - buru dalam mengerjakan soal tanpa memperhatikan jawaban yang mereka kerjakan tepat atau tidak. 


\section{KESIMPULAN}

Kesimpulan dari hasil analisis kesulitan siswa dalam mengerjakan soal pada materi aritmatika sosial kelas VII di SMP Al- Barokah Sindangkerta. Dari hasil analisis butir soal yaitu banyak siswa yang mengalami kesulitan mengerjakan soal pada butir soal nomor 1, dan dari hasil analisis butir soal nomor 1 di kategorikan sebagai soal yang tingkatnya sulit, kemudian butir soal nomor 2, 3, dan 4 dikategorikan soal tingkat sedang dan nomor 5 memiliki kategori soal yang mudah. Dan dari hasil analisis butir soal ini terdapat beberapa faktor yang mempengaruhi siswa kesulitan dalam menyelesaikan butir soal yaitu kurangnya minat belajar siswa terhadap matematika, kurangnya pemahaman konsep matematis siswa terhadap materi aritmatika sosial dan siswa kurang teliti dalam membaca dan memahami soal cerita yang disajikan. Kemudian dalam penelitian ini pun peneliti mendapatkan beberapa tife kesalahan siswa dalam mengerjakan soal cerita pada materi aritmatika sosial dengan menggunakan tahap analisis Newman, yaitu terdapat empat tife atau faktor kesalahan yang sering dilakukan siswa dalam mengerjakan soal pada materi aritmatika sosial, diantaranya kesalahan memahami soal, kesalahan transformasi, kesalahan dalam keterampilan proses dan kesalahan penulisan jawaban. Dalam hal ini siswa memang masih belum memahami langkah langkah atau prosedur dalam mengerjakan soal yang seharusnya sehingga siswa sering mengalami kesulitan dan kekeliruan dalam mengerjakan soal.

\section{UCAPAN TERIMA KASIH}

Dan peneliti sangat berterima kasih kepada pihak-pihak yang selama ini sudah membantu terlaksannya penelitian analisis kesulitan siswa pada materi aritmatika sosial kelas VII yang lokasi penelitiannya di SMP Al- Barokah Sindangkerta. Peneliti ucapkan banyak terima kasih kepada kepala sekolah SMP AlBarokah Sindangkerta yang telah mengizinkan peneliti untuk mengikuti penelitian dan juga kepada siswasiswi yang baik hati yang berkenan diajak kerja sama dan membantu dalam penelitian ini sehingga peneliti mampu melaksanakan penelitian hingga penyusunan artikel ini. Juga tidak lupa peneliti ucapakan terima kasih kepada dosen pembimbing yaitu Bapak Wahyu Setiawan,S.Pd.,M.Pd selaku pembimbing yang selama ini telah membimbing saya untuk melakukan penelitian hingga penyusunan artikel ini. Dan yang utama peneliti ucapkan terimakasih kepada kedua orang tua peneliti dan segenap keluarga besar yang telah memotivasi dan mendukung penuh peneliti dari awal hingga sekarang.

\section{REFERENSI}

Evijayanti, W. (2016). ANalisis Kesulitan Siswa Kelas VII Smp Negeri 3 Kartasuara Dalam Menyelesaikan Soal Cerita Aritmatika Sosial. 1-13.

Firmansyah,. Sofnindar, R. (2018). Analisis Kesulitan Belajar Matematika Siswa Menurut Lerner Dengan Kepribadian Artisan Dalam Menyelesaikan Soal Cerita Materi Aritmatika Sosial Kelas VII SMP. Journal of Materials Processing Technology, $\quad 1(1), \quad 1-8$. http://dx.doi.org/10.1016/j.cirp.2016.06.001\%0Ahttp://dx.doi.org/10.1016/j.powtec.2016.12.055\%0 
Ahttps://doi.org/10.1016/j.ijfatigue.2019.02.006\%0Ahttps://doi.org/10.1016/j.matlet.2019.04.024\%0 Ahttps://doi.org/10.1016/j.matlet.2019.127252\%0Ahttp://dx.doi.o

Fitri, Nadya M.A., Adirakasiwi, Alpha Galih., Utami, M. R. (2018). Analisis Kesulitan Siswa SMP Dalam Menyelesaikan Soal Cerita Aritmatika Sosial. 1, 295-302.

Halim, F. A., Rasidah, N. I., \& Prodi, M. (2019). Analisis Kesalahan Siswa Dalam Menyelesaikan (Analysis of Student Errors in Resolving the Problem of. Jurnal Pendidikan Matematika, 02(01), 35-44.

Hamidah, N., \& Setiawan, W. (2015). Analisis minat belajar siswa sma kelas xi pada materi matriks. Jurnal On Education, 01(02), 457-463.

Kurniawan, A., \& Fitriani, N. (2020). Analisis kesalahan siswa dalam menyelesaikan soal aritmatika sosial. Journal On Education, 02(02), 225-232.

Luh, N., \& Ekayani, P. (2017). Pentingnya Penggunaan Media Pembelajaran Untuk Meningkatkan Prestasi Belajar Siswa. March. https://www.researchgate.net/publication/315105651\%0APENTINGNYA

Nuraeni, R., Ardiansyah, S. G., \& Zanthy, L. S. (2020). Permasalahan Matematika Aritmatika Sosial Dalam Bentuk Cerita: Bagaimana Deskripsi Kesalahan-Kesalahan Jawaban Siswa? Teorema: Teori Dan Riset Matematika, 5(1), 61-68. https://doi.org/10.25157/teorema.v5i1.3345

Paramitha, N., \& Yunianta, T. N. . (2017). Analisis Proses Berpikir Kreatif dalam Memecahkan Masalah Matematika Materi Aritmatika Sosial Siswa SMP Berkemampuan Tinggi. Jurnal Miitra Pendidikan (JMP Online), 1(10), 983-994. http://e-jurnalmitrapendidikan.com

Rahmawati, N. S., Bernard, M., \& Akbar, P. (2019). Analisis Kemampuan Komunikasi Matematik Siswa Smk Pada Materi Sistem Persamaan Linier Dua Variabel (SPLDV). Jurnal Cendekia: Jurnal Pendidikan Matematika, 1(2), 344-352.

Ratnasari, S., \& Setiawan, W. (2018). Analisis kesulitan belajar siswa pada materi himpunan. Journal On Education, 01(02), 473-479.

Yanti, R. N., Melati, A. S., \& Zanty, L. S. (2019). Analisis Kemampuan Pemahaman dan Kemampuan Komunikasi Matematis Siswa SMP Pada Materi Relasi dan Fungsi. Jurnal Cendekia: Jurnal Pendidikan Matematika, 3(1), 209-219. https://doi.org/10.31004/cendekia.v3i1.95

Zulfikar, M. I.A., Achmad, N., Fitriani, N. (2018). Analisis Kemampuan Penalaran Matematik Siswa SMP di Kabupaten Bandung Barat pada Materi Barisan dan Deret. Jurnal Pendidikan Tambusai, 2(6), $1802-1810$. 